\title{
On the Reform and Practice of Ideological and Political Teaching for Students of Sino-foreign Cooperative School-Running Project Under "Great Ideological and Political" Education Pattern
}

\author{
Tianwen Zhang* \\ Changchun Institute of Technology \\ Changchun 130012, China
}

\begin{abstract}
With the gradual attention of the State and the Ministry of Education to Chinese-foreign cooperatively-run schools, the ideological and political teaching of Chinese-foreign cooperatively-run schools has been widely promoted, reformed and innovated. In order to promote the improvement and development of ideological and political courses for Chineseforeign cooperatively-run schools, we must deepen the concept of ideological and political education. Nowadays, the problem facing Chinese-foreign cooperatively-run schools is to improve the teaching quality of ideological and political courses. In this article, the author mainly summarizes the idea of ideological and political education of Chinese-foreign cooperatively-run school students, analyzes its existing problems, and puts forward relevant countermeasures.
\end{abstract}

Keywords-Ideological political; Sino-foreign cooperativelyrun schools; Practice Teaching

\section{INTRODUCTION}

Sino-foreign cooperation in running schools is an important part of higher education in China, and an important form and path to promote the internationalization of higher education in China and realize "studying abroad locally". The Chineseforeign cooperatively-run university with independent legal personality, the Chinese-foreign cooperatively-run college with the nature of secondary college and the Chinese-foreign cooperatively-run school project constitute the "ladder" structure of Chinese-foreign cooperatively-run school, and it is an important part of the Chinese-foreign cooperatively-run school system. Chinese-foreign cooperatively-run schools have the characteristics of high starting point, high standard and high cost, as well as the characteristics of localization, specialization, globalization and marketization. The "ladder" mode of running a school determines that the internationalization of Chinese higher education in the future must recognize the three modes of Chinese-foreign cooperation in running a school, and follow the objective law of spiral rise of Chinese-foreign cooperation in running a school. There are many differences between Chinese-foreign cooperatively-run schools and ordinary students, such as motivation and purpose of study, superior economic conditions and lower scores.

The main purpose of ideological and political courses is to improve students' ideological and moral character and comprehensive accomplishment, and to help students establish their own values of life and their own beliefs. However, to analyze the current situation of ideological and political education, there are still problems to be improved, and not to keep up with the reform and innovation of the times, teachers cannot achieve efficient teaching achievements. In today's era, teachers should not only pay attention to the improvement of students' ability, but also take different educational methods to students in Chinese-foreign cooperatively-run schools, focus on the implementation of quality education, and promote the all-round development and progress of students.

\section{NEW REQUIREMENTS FOR IDEOLOGICAL AND POLITICAL TEACHING IN CHINESE-FOREIGN COOPERATIVE SCHOOLS PROJECT}

Ideological and political teaching is a unique education in our country, which mainly helps students to establish the correct concept of life. In recent years, as the ideological and political education is constantly valued, so, in order to promote the development of ideological and political education, put forward several requirements, these are:

\section{A. Requires Chinese-foreign Cooperatively-run Schools to Teach Ideological and Political Courses Strategically}

Chinese-foreign cooperatively-run school ideological and political teaching courses must be strategic, enhance the strategic work. Under the educational background of "great ideological and political", the development of educational work needs to be carried out according to the documents and requirements issued by the state, drawing on the guidance and suggestions of the state, and seeking new educational methods. Through the use of new educational means to cultivate students' comprehensive literacy, let them actively accept the 
idea of ideological and political education. Teachers take the initiative to explore effective teaching methods, strive to obtain significant teaching results, and cultivate talents for the country.

\section{B. Innovative Teaching of Chinese-foreign Cooperatively-run Ideological and Political Courses is Required}

The times have been developing and improving, and the thought of the times is also changing. To promote the development of a country, we must encourage talents to take the initiative to innovate and follow the trend of the development of the times. For the development of students' ideological and political education, we should also attach importance to innovation, take "great ideological and political" as the teaching background, especially a considerable number of students in the Chinese-foreign cooperatively-run school program choose to study abroad, constantly integrate new ideas and ideas, and efficiently carry out ideological and political education for students. The innovation of ideological and political teaching not only has the integration of new ideas, but also requires teachers to adopt novel teaching methods and broaden the scope of quality teaching. This It is a new requirement under the background of "great thought and politics", and also the promotion of students' comprehensive accomplishment and teachers' teaching work level.

\section{Requirements for Chinese-foreign Cooperatively-run Ideological and Political Education}

When teachers carry out teaching work, they must teach students according to their different learning levels. Take the students themselves as the basic, comprehensive teaching work cannot be separated from the student body to carry out the work. That is, teachers to carry out ideological and political teaching to them, must be based on the general basic situation of each student, referring to their development trend, to establish their own teaching system, so that ideological and political education can play a practical role. In the process of carrying out teaching, we must focus on students, combine their needs and ideals, actively innovate their own teaching programs, seek the weakness of students, and carry out targeted education work.

III. ON THE TEACHING OF IDEOLOGICAL AND POLITICAL COURSES IN CHINESE-FOREIGN COOPERATIVE SCHOOLS UNDER THE “GREAT IDEOLOGICAL AND POLITICAL” EDUCATION PATTERN

\section{A. Backward Idea of Ideological and Political Education}

Ideological and political education needs to follow the development of the times, renew their own teaching ideas, absorb the new ideas produced by the progress of the times, so as to support the ideological and political education. Therefore, this requires teachers to dare to innovate their own ideas, discard their previous ideas, accept the arrival of new ideas, and carry out high-quality teaching to students. However, in the present situation, most teachers still keep the previous teaching ideas and concepts, some schools in the great ideological and political education did not implement ideological and political teaching, ignoring the Chinese-foreign cooperatively-run school program students "abroad fever" this characteristic, lack of students We carry out professional quality education and political quality education, which reduces their enthusiasm for learning.

\section{B. Backward Mode of Ideological and Political Teaching}

The most important teaching part of ideological and political education is the need for a teaching mode that keeps pace with the times, follows the progress of the times, changes its own teaching mode, and prevents the phenomenon of selfrestraint. However, the current teaching situation is that many colleges and universities that open classes of Sino-foreign cooperatively-run schools have not actively changed their teaching mode, their teaching mode is lack of innovation, has long been unable to keep up with the trend, can not promote the efficient development of teaching. Some schools carry out ideological and political teaching, only to complete the teaching work, not really based on the students, according to their actual situation, promote their development, not conducive to their correct society the establishment of values.

\section{Backward Approach to Ideological and Political Teaching}

In addition to updating the school's teaching model, it is necessary to absorb novel teaching methods. Under the teaching background of "great ideological and political", schools and teachers must introduce innovative analysis of the current situation. Many teachers and schools lack the introduction and innovation of new teaching methods. Most teachers carry out ideological and political education to their students according to their previous teaching methods, which is not conducive to the thorough and extensive development and implementation of ideological and political education. For example, some colleges and universities in the current political hot spots, the lack of social development trends and analysis of the current situation of economic development, from the beginning cannot stimulate Their interest in learning leads them to be unable to receive ideological and political education efficiently.

IV. REFORM AND INNOVATION OF IDEOLOGICAL AND POLITICAL TEACHING IN CHINESE-FOREIGN COOPERATIVE SCHOOL-RUNNING PROJECT UNDER "GREAT IDEOLOGICAL AND POLITICAL” EDUCATION PATTERN

\section{A. Enhanced Awareness of the Importance of Ideological and Political Teaching}

Schools and teachers must pay attention to the development of ideological and political education to improve students' comprehensive literacy and ideological and moral level. At the present stage, most schools and teachers ignore the important points of ideological and political teaching, and students do not accept ideological and political teaching seriously, which makes many colleges and universities that set up Sino-foreign cooperatively-run schools have not been fully carried out in ideological and political teaching, and students' ideological and political education is lacking. As a result, this alerted the relevant colleges and teachers to realize the importance of ideological and political teaching, play the role of ideological and political education. The school may require the teacher to regulate the reasonable teaching plan, according to the times 
change and the progress, unceasingly introduces the new ideas and new ideas, students as the basis, according to their actual situation, to promote the work.

\section{B. Innovative Ideological and Political Teaching Mechanism}

According to the overview and analysis above, if ideological and political education wants to obtain remarkable results, it is necessary to establish a unique teaching system, and to innovate with the development of the times, to ensure the sustainable development of ideological and political education, and to attach importance to the efficient development of the teaching process. To establish a system of ideological and political teaching, first, to increase the strength of the management of ideological and political teaching, to build a corresponding teaching mechanism, according to the development demands of students, to create a high-quality team of teachers; second, to establish a variety of activity platforms on which students can work, or to organize their own cultural activities to create a good learning environment and atmosphere; In addition, we should work closely with the various departments of the school to carry out ideological and political work together to promote the progress of ideological and political work.

\section{Strengthening the Construction of Ideological and Political Teachers}

Teachers play a major role in ideological and political teaching, and guide students to accept ideological and political teaching. Therefore, the teaching level of teachers is related to the quality of ideological and political education in Sinoforeign cooperatively-run schools, which requires schools to teachers' strength and improve teachers' teaching level. The school can actively introduce talents from other schools, help the school to promote ideological and political education for students, or invite educational experts in this field to give lectures for teachers to study, conduct professional training for teachers, set corresponding teaching objectives for them, urge them to complete, strengthen their sense of responsibility and enhance their sense of responsibility teaching quality. Teachers' work is related, teachers in various departments can discuss and explore the effective ways of ideological and political education for students, and carry out ideological and political teaching in an all-round way.

\section{Enrich the Content of Ideological and Political Practice Teaching by Combining the Characteristics of Vocational Teaching}

Each project has its own teaching characteristics and professional characteristics, and the countries that cooperate in running schools also have different cultural and political backgrounds. When carrying out ideological and political education for students, we must combine the professional characteristics of the cultural characteristics of the project and the cooperative country, grasp the development trend of their future occupation, perfect the teaching system, contact the students' personal reality, and promote the development of ideological and political affairs efficiently. Each student's own situation is different, they also have their own career development direction and goal, so, in combination with these situations, teachers need to show their leading role and cultivate students' basic professional elements raise, teach them how according to their own situation, contact their own employment needs, to improve their professional accomplishment and comprehensive quality, encourage them to actively think about problems and explore the answers to questions. For example, the development of innovative entrepreneurial activities, professional and cultural publicity activities and "three go to the countryside" and so on, teaching and practical effective combination, contact.

\section{CONCLUSION}

To sum up, carrying out ideological and political teaching efficiently is beneficial to the students' own progress and development, and also to the overall progress of higher vocational colleges. With the renewal of the times, the problem that Chinese-foreign cooperatively-run schools must face is how to promote the development of ideological and political education effectively, and how to innovate the means of ideological and political education. Therefore, at the present stage, the school must actively analyze the problems existing in ideological and political teaching, put forward solutions, actively innovate teaching means, improve the teaching level of teachers, and expand the overall teaching strength of the school at the same time.

\section{REFERENCES}

[1] Ling Liu. Education Reform and Practice of Ideological and Political Course in Higher Vocational Education [J].] Knowledge economy ,2017(24):165 167

[2] Jianglan Ran. Ideological and political teaching in higher vocationa colleges under the educational pattern of "Great Ideological and political J]." Western Quality Education ,2018,4(05):29-30.

[3] Xinyu Bao. Education Reform and Practice of Ideological and Political Course in Higher Vocational Education [J].] Technology Wind ,2019(36):48. 